\title{
An Appraisal of the Crisis in Darfur in Western Sudan and the Prospect for a Lasting Peace
}

\author{
Mamman Musa Adamu
}

\begin{abstract}
:
The Darfur crisis in western Sudan started in February 2003. It has to date claimed the lives of an estimated number of 200,000 people and another 2.5 million have been displaced and are now living in make shift refugee camps in Chad and neighbouring countries. All attempts to broker peace among the major warring factions had proved abortive and there is little or no hope that the displaced people would one day return to their villages. The killings, raping, suffering and starvation had continued despite the presence of the African Union troops which numbered about 7000 and deployed since 2004. A lot of propaganda, misinformation, fabrications and distortions have gone across to the public in trying to explain the causes and attendant consequence of the said conflict. These have clearly stood on the way to a real understanding of the genesis of the crisis for a lasting peace to be obtained and peace building to be accelerated, and end this bloodshed and suffering that had been the bane of the region for the past five years. This paper is an appraisal of the various views and opinions that had been put forward by different interest groups on the causes of the crisis, its impact and the way forward towards the attainment of peace.
\end{abstract}

\section{Introduction}

The conflict in Darfur erupted on 26th February, 2003 when a joint force of two rebel groups, the Justice and Equality Movement (JEM) and the Sudan Liberation Army (SLA) or the Darfur Liberation Front (DLF) carried out some devastating attacks on Golo the headquarters of Jebel Marra district. The rebels succeeded in killing over 685 policemen, destroyed over 80 police stations and wounded 500 others. A similar attack was waged on 25th April 2003 on a sleeping garrison at Al-Fashir where 75 soldiers, pilots and technicians were killed and 
32 were captured including the commander of the airbase. Four Antonov bombers and seven helicopter gun ships were also destroyed. The rebels on their part lost 900 soldiers. Other attacks were carried out in May 2003 by the SLA on a battalion at Kutum killing 500 and taking 300 prisoners. This was followed by another attack on Tine in mid July 2003 and about 250 were killed by the rebels. The rebels claimed that they carried all these attacks because Darfur has been marginalized and underdeveloped by the government of Al-Bashir (Flint and De Wall, 2006). The government responded to the rebel attacks by forming and arming the Janjaweed, an irregular paramilitary force consisting of its army, air force, and local defense forces made up of national and local volunteers and other supportive local language groups to fight the rebels. It did this for two reasons: One of these was that the government was not sure of the loyalty of its army which had a preponderant number coming from the region. Over $50 \%$ of the Sudanese military were said to come from Darfur and secondly the government did not want to be accused of targeting some people for elimination. The government had, however, consistently denied having anything to do with the Janjaweed (BBC News, 27th February, 2007). By April 2004, the Janjaweed had an upper hand in the battle with the rebels. It succeeded in killing several thousands of people from the bases of the rebels mainly in Darfur and driving a million more from their homes. Several others, about 100,000, were forced to flee into neighbouring Chad pursued by the government militiamen. Rape was a major weapon used by the militia against women to humiliate them and render them unclean and ostracized from their societies. The war had raged on against the rebels since then with more killings, raping and many more being forced out of their homes. As late as 8th February, 2008, more than 30,000 people were reported to have been displaced in a government backed militia attack on the villages of Abu Surouj, Sirba, and Seleia in West Darfur. An unknown number of children aged 12-18, especially boys were declared missing, and several buildings were burnt all in an attempt to route one of the opposition groups, the Justice and Equality Movement from these places (Flint and De Wall, 2006,) 


\section{Causes of the Crisis}

The crisis in Darfur had been made obscure, confusing and complicated as a result of the flurry of explanations that have been put across by different interest groups, organizations, individuals and the print and electronic media. So far the crisis has been interpreted in ethnic/religious terms, some had viewed it as being caused by marginalization and still others had reported it as another case of genocide. There were other explanations that had seen it as a longrunning fight for political supremacy between the two factions of the ruling Sudanese Islamist Movement, the Popular Congress Party led by Hassan Turabi and the ruling National Congress led by President Al-Bashir. It is important to examine each of these interpretations to see how far they can be taken to explain the crisis in Darfur.

\section{Ethnic/religious explanation:}

The crisis in Darfur has been widely portrayed as an ethnic cleansing by the Arab militias against Black African villagers or a conflict between Arab and African populations. It was presented as a racial conflict between the light skinned 'Arabs' drawn mostly from the camel- herding nomads of Baggara 'tribes' of northern Rizeigat and the land- tilling black 'African' ethnic groups of Fur, Zaghawa and Massalit . The Knight Ridder Newspapers of 20th August, 2004 cited the destruction of schools in Darfur by the Arab militias as a good example of the attempt to wipe out the black culture. Nicholas Kristof (2004) was also emphatic about this racial difference when he alleged that the black Africans were driven from their homes by lighterskinned Arabs, the Janjaweed. It is however clear that the war was not racial in the way it was seen as the Arabs just trying to uproot Africans from their homes. The crisis was much more complex than that. Moreover, so many other analysts such as Ateem Selsi, de Wall etc. had shown that there is little or no racial difference between the language groups; Arab or African as a result of a long period of inter marriage and so much mixing. The language groups were all black and were physically indistinguishable. Ateem Selsi (2004) particularly noted that the people in Sudan look alike so much so that you cannot 
tell from the features of the body that one is Arab or African. He acknowledged being lighter in complexion than most of the so-called Arabs as an African. De Waal (2006), in the same way, challenged this stereotype by showing that the Darfur Arabs are black, indigenous African Muslims just like the non-Arabs. He noted interalia that the Zaghawa are indigenous black and African sharing distant origins with the Berbers of Morocco and other ancient Saharan peoples. But that the name of the 'Bedeyat' the Zaghawa's close kin 'Bedeyin' or Bedouins is a pointer to their true origin. He added that the Zaghawa's adversaries in this war, the Darfurian Arabs, are Arabs in the ancient sense of 'Bedouins', meaning desert nomad and concluded that the Darfurian Arabs too, are indigenous, black and African and that there are no discernible racial or religious differences between the two: all have lived there for centuries.

The international commission of inquiry on Darfur which was set up by the former Secretary General to the UN, Mr. Kofi Anan also observed that the various 'tribes' that have been the object of attacks and killings, chiefly the Fur, Massalit and Zaghawa language groups do not appear to make up ethnic groups distinct from the ethnic group to which persons or militias that attack them belong. The committee concluded that the ethnic groups speak the same language (Arabic) and embrace the same religion (Islam) (Report of the International Commission on Darfur to the UN Secretary General (PDF) UN 25th, January, 2006, p.129).

The argument that the crisis was racial and ethnic was, therefore, not only unfounded but malicious and dangerous and obscures the reality of what is happening in the Darfurian region of western Sudan. Similarly, the portrayal of the crisis as a western plot to undermine Islam is another attempt to obliterate the true situation.

\section{A Case of Genocide?}

Related very closely to the racial argument, was the claim that the Darfur crisis was another case of genocide i.e. a deliberate plan or intention by the government to kill or exclude a whole population 
group as was the case in the Holocaust, the Armenians in Turkey or more recently in Rwanda or Kosovo and other parts of former Yugoslavia. Eric Reeves (2004) is one of the leading advocates of this argument. He was of the opinion that the government in Khartoum had a singular objective of eliminating the African language groups in Darfur out of Sudan. He alleged that a document seized from a Janjaweed official directed all the commanders and security officers to change the demography of the area and make it void of African tribes by killing the people, burning their villages and farms, terrorizing them and confiscating their property and forcing them out of the region. The United States of America had also declared the crisis as genocide based on a study that was commissioned and funded by sections of the American government and carried out by the New York based physicians for human rights. The former U.S Secretary of State, Colin Powell noted that genocide was committed in Darfur while addressing the Senate Foreign Relations Committee in September 2004 after a visit to Sudan (Interpress Service, 2007). There had been several negative reactions, however, towards this approach to the crisis. Peter Quayle (2005) has for example shown that it is wrong to label the events in Darfur as genocide as people are attacked only because of the possibility they shelter and sustain rebels but outside the conflict area they were unharmed. The UN Under Secretary for Humanitarian Affairs, Jan Egeland was also of the opinion that the term ethnic cleansing or genocide did not fit the events in Darfur as the same 'tribes' are represented both among those who are cleansed and those who are cleansing ( PANA, 2004). It is also important to note what Medicins Sans Frontiers or Medicine without borders have said over the conflict. They noted that there was no systematic target-targeting one systematic group or another one. Bradol (2004) said that the use of the term genocide was inappropriate as their teams had not seen evidence of the deliberate intention to kill people of a specific group or eliminate them altogether.

Similarly, the UN under Kofi Annan, the AU under President Obasanjo of Nigeria and the EU's fact finding mission have all denied 
that the situation in Darfur was a case of genocide even though there were killings and destruction of lives and property. The attitude of the government towards the displaced people was another pointer to the fact that the conflict does not look like genocide. The government has been trying to return the displaced people back to their homes. By November 2004, they had returned 270,000 to their places of origin. The government has also, contrary to expectation under a typical genocide scenario, been allowing foreigners and especially journalists into the area unobstructed, to report about the situation in the region. A total of about 8500 aid workers including reporters of The Times, The Washington Post, The Telegraph, The Guardian, The Economist, etc. spent weeks and months in Darfur (Hoile, 2005).

\section{Claims of Marginalization and Underdevelopment:}

The claim by the insurgents and their apologists that the conflict was caused by abysmal neglect, negligence, marginalization and general underdevelopment of Darfur by the government of Al-Bashir has been repudiated by the government. The government used statistical data to prove that Darfur is not more underdeveloped than other parts of Sudan. In the field of education it demonstrated that at the time it came into power in 1989, there were only 16 high schools and 241 primary schools with a total enrolment of 27,000 students and no single university; but by 2003 they had increased the number of the high schools to 251, the primary schools to 241, built 3 universities and the enrolment rose to 440,000. Similarly, the number of hospitals rose from 3 in 1988 to 23 by 2001 and from about 20 to 44 health centres within the same period. The government further claimed that it raised water supply from 1,200,000 cubic metres in 1989 to 3,100,000 cubic metres in 2003 through the installation of 110 deep ground wells, the rehabilitation of 133 others, building of 30 dams, 43 dykes, the drilling of 842 hand pumps and the rehabilitation of 839 others. Power generation rose from 230 kilowatts in 1989 to 4,500 kilowatts by the year 2000 and provided 3 airports at al- Fasher, Nyala and alGeneina along with 3 aerodromes and numerous roads across the length and breadth of Darfur. The government of Al-Bashir has in 
addition shown that even at the political level, there is no marginalization, whatsoever, on Darfur. Four state governors and eight government ministers are said to have come from the region with many more representing at the National Assembly. Others were members of the supreme and constitutional court of the country (Hoile, 2005). The perennial attacks by the armed rebels on some of the key educational and development projects as well as individuals engaged in these projects had further cast aspersions on the claim of marginalization. The Chairman of North Darfur once expressed surprise at the way the rebels were attacking some development projects in the state while claiming lack of development as the cause of their movement (Sudan Vision, 2004). One of the most prominent human right activists in Sudan, Ghazi Suleiman (2004) also noted that the conflict has nothing to do with marginalization or the inequitable distribution of wealth. If all these claims by the government and testimonies of others were anything to go by, then the crisis was certainly not caused by the reason of marginalization.

\section{Power Struggle within the Ruling National Congress Party:}

There were strong indications that the conflict in Darfur was the outcome of power struggle between the two factions of the Sudanese Islamist Movement, the Popular Congress Party and the ruling National Congress Party. Ghazi Suleiman (2004) described the conflict as a struggle to seize power in Khartoum and the battle field was in Darfur. He apportioned the blame on Hassan Turabi and said that if the government would release him and come to terms with him, the fight would stop in a week. Sudarsan Raghavan (2004) of the Knight Ridder Newspapers also interpreted the conflict as part of a long running fight for political supremacy between Sudanese president Omar al-Bashir and an ardent supporter of Osama bin Laden in the person of Hassan Turabi. He noted that the latter was Sudan's most powerful man for 15 years and had been maneuvering political affairs as the speaker of the parliament until he was sidelined in 1999. The General Secretary of the Pan-African Movement and Co-Director of Justice Africa, Tajudeen Abdul-Raheem (2004) also expressed the 
same view that Darfur was a victim of the split within the National Islamic Front personified by Al-Turabi and his former protégé AlBashir.

Others like de Wall (2006), variously commented that Al-Turabi's ultimate goal was the presidential palace in Khartoum and a stridently Islamic Sudan and that the government of Al-Bashir was afraid of him. It was also believed that his supporters form the core of the rebel groups, an allegation that he had never denied. The differences between the factions had been attributed by de Waal (2006) to be over ideology, foreign policy, the constitution, and ultimately power itself. Al-Turabi was said to be opposed to Khartoum's association with America, including Sudan's considerable assistance in the war on terrorism and the concessions Khartoum made in the peace process with southern Sudan. He was accused of having the secret agenda of overthrowing the government of Sudan and replacing it with a more hard line Islamic regime. One way of achieving this was through the publication and distribution of the 'Black Book' by his Popular Congress Party in May 2000, alleging Khartoum's marginalization and neglect of Darfur and claiming that Sudan's political elite was dominated by a northern Arab clique. According to de Waal, the book was a key step in the polarization of the country along politically constructed racial rather than religious lines and it laid the basis for a coalition between Darfur's radicals who formed the Sudan Liberation Army (SLA) and its islamists who formed the Justice and Equality Movement (JEM). The colossal lost of lives and property and the displacement of millions of people were as a result of the resolve by the government of Al-Bashir to defeat JEM and SLM at any cost. The government believed that Turabi was using Darfur as a tool to return to power in Khartoum and this has been its main reason for refusing to talk to the rebels particularly JEM and to defiantly refuse the intervention of international organizations like the UN. Hence the power struggle within the ranks of the Sudan's ruling party seems to be the actual cause of the crisis and ultimately the major reason why 
people are being killed, maimed, raped and displaced in Darfur since 2003.

\section{International Interests in the Conflict:}

The international response to the crisis in Darfur was largely determined by the interests of the powers in the conflict. At the initial stage the world's most powerful countries chose to be complacent or reticent but with calls on the United Nations to take action. The UN on its part abandoned the responsibility to the African Union which then deployed a token force without a mandate to protect civilians. The world's most powerful countries remained aloof, indifferent and sometimes even aided the combatants, leading to the escalation of the crisis, until recently. This attitude was attributed to series of factors. The first of this has to do with the attempts by the western powers to counter Chinese-Sudanese Oil Cooperation and to defer further oil deals by China in the region. Fidelity, a subsidiary of the statecontrolled China National Petroleum Corporation was said to own a major stake in Sudan's national oil consortia and maintains extensive operations there. It purchased more than half of Sudan oil exports in 2005. It is now being speculated that the profits which is up to 2 billion dollars every year, from these sales is what is enabling the Khartoum government to buy weapons with which to continue its military operations both directly and by proxy in Darfur (Johannesburgh Interpress Service, 2007). China was further accused of providing weapons and aircrafts to Sudan in order to obtain oil and gas and using its veto on the UN Security Council to protect Khartoum from sanctions, water down or make toothless every resolution on Darfur in order to protect its interests in Sudan. The Sudanese government was said to have purchased about 100 million dollars in arms from China and used the weapons against the rebels in 2007. This has been the reason behind the recent calls to boycott the forthcoming Olympics in China made by the French presidential candidate, Francois Bayrou, actor and UNICEF Goodwill Ambassador, Mia Farrow, Genocide Intervention Network 
Representative, Ronan Farrow as well as the Sudan scholar and author, Eric Reeves (Sudan Tribune, 11th February, 2007).

Secondly, there was the issue of the involvement of al-Qaeda with the rebel groups like the JEM and Al-Turabi. Al-Qaeda has been noted to be interested in Darfur on account of its physical inaccessibility, its Islamic heritage, inaccessibility to western intelligence services and its porous borders, making it a very attractive location to hide in and wage an attack. Turabi is said to be very close to Osama bin Laden and shared his vision of a worldwide struggle to establish a pure caliphate. The members of JEM have also received some of their training with al-Qaeda instructors including specialists in guerilla and urban warfare and logistics in the 1990's. JEM is also suspected of having links with several other militant Islamist groups in Africa and around the world (Hoile, 2004). The US and other countries of Western Europe were, therefore, hesitant to act from the beginning because they wanted to see al- Qaeda routed out of the area.

Thirdly, there were also reports about American involvement in sustaining the insurgency. Eric Morgolis (2004) noted that the American CIA was supplying arms and money to the rebels in Darfur and was using the rebels as it did in Southern Sudan's thirty year old insurgency to destabilize the Khartoum regime whose policies were deemed insufficiently pro-American and too Islamic. It is further said to be eyeing Sudan's oil as well as other precious commodities like water. On the other hand, America is said to be reluctant to act in the conflict because of what John Prentergast called the clash between human rights principles with post 9/11 counter terrorism operatives. He attributed the reluctance on the part of the United States of America to act to the influence of Osama bin Laden in Darfur. America is now said to be using bin Laden's former ally, Salah Abdallah Gosh as an active counterterrorism partner, detaining terrorism suspects and turning them over to the US, expelling Islamic extremists and raiding suspected terrorists homes and handing evidence to the FBI. Gosh is currently the head of security of the government and playing a leading role in the counter insurgency 
strategy which relies on the Janjaweed militias to destroy the villages in Darfur that have linkages with bin-Laden. Prentergast argues that it is this deepening intelligence sharing relationship between Washington and Khartoum that blunted any US response to the state sponsored violence that exploded in 2003 and 2004. America felt that access to Gosh's information would be jeopardized if the Bush administration confronted Khartoum on Darfur. The US has also been said to be pursuing a peace deal between Southern Sudanese rebels and the regime in Khartoum since 2001 and didn't want to undermine that process by hammering Khartoum over Darfur (Africa Focus, 2006). It is worth noting that Bush administration deliberately refused to act on what Bush himself repeatedly called genocide nearly five years into the crisis. On 29th May, 2007, however, President Bush, apparently, reacting to home pressure and international condemnation of the conflict and American indifference to it, pronounced sanctions which made it a crime for US companies and individuals to knowingly do business with 31 companies from the American financial system (The White House, 2007). The sanction was of course, welcomed but it was said to be long overdue and of no consequence since China and Russia still sell arms to Khartoum which technically are not for use in the western war. Similarly, many see it as a contradiction, paradox and mere pretence for the US to impose sanctions on a country that it considers being of vital importance in regional security and which it needs its support in the long war against al-Qaeda.

As mentioned earlier, Sudan is reported to be providing intelligence reports to the west, especially on al-Qaeda's penetration of North Africa and sub-Saharan Africa as indicated in the recent Islamic terrorist attacks in Algeria, Morocco and northern Nigeria and its operations in Iraq as well as the Islamic resurgence in Somalia following the invasion by Ethiopia. Lastly some segments of the Arab media have criticized the publicity that is being given to the crisis as being exaggerative and diversionary with the intention of covering the crimes being committed by the Israelites in Palestine and Iraq. They 
have claimed that "the western attention to the Darfur crisis is a cover for what is really being planned and carried out by the western forces of hegemony and control in our Arab world (Al- Hayat ( English edition) 13th April, 2007). Eritrea was also alleged to be rendering support to the rebels militarily, logistically, and politically. Among other things, it has been said to have provided the avenue for the signing of an agreement between the Darfur gunmen and elements of the Beja Congress, armed anti- government group based in Eritrea as well as hosting Darfur rebel organizations. The government of Sudan was said to have lodged a formal complaint to the UN and AU about this attempt by Eritrea to destabilize it (Asmara 14th July, 2007 and Deutche Press Agentur, 5th January, 2004).

\section{The Impact of Darfur Conflict:}

The conflict in Darfur has led to enormous lost of lives and property and the displacement of people. It is significant to note that there has so far been no concensus as regards to the number of people that had perished as a result of the conflict. The estimated number has ranged from 50,000 given by World Health Organisation (WHO) in September, 2004 to 500,000 as given by Eric Reeves in February, 2007 and 400,000 as given by the Coalition for International Justice and been cited by the UN.The latest research published in September, 2006 in the journal 'Science' has put the number of deaths above 200,000 without distinction made between those who died as a result of violence and those dying as a result of starvation or disease in refugee camps (BBC News 27th February, 2007). The government has maintained that only 9000 people have been killed. By 2004 the number of displaced people had been put at 2.5 million with more than 230,000 in eastern Chad and about 515,000 in other neighboring countries, mainly the centralAfrican Republic, Democratic Republic of the Congo, Ethiopia, Kenya and Uganda with fewer numbers in Libya and Egypt. To date the UN office for the Coordination of Humanitarian Affairs (OCHA) has reported that there are over 250,000 Sudanese refugees and over 180,000 internally displaced 
persons in eastern Chad who are heavily reliant on humanitarian aid for their survival (UN News Service, 2007).

The conflict also destabilized some neighbouring countries especially along the Chad- Sudan border and the whole region. A strained relationship between Chad and Sudan is evident as the two countries accused each other of supporting destabilizing forces. Sudan accused Chad of backing Darfur's National Redemption Front rebels who have been carrying out cross- border raids. There are also allegations that many of these rebels have been assimilated into Chad's national army, having come from the same ethnic group with Chad's President Idriss Derby, a charge the Chad government denied. Chad, on the other hand, accused Sudan government backed militia, the Janjaweed, of attacking villagers in Chad and some of the more than 200,000 refugees that came to eastern Chad after fleeing violence in Darfur. As late as March, 2007, Janjaweed forces were said to have crossed into Chad and killed up to 400 people. Chad, further, has consistently accused Khartoum of backing the Union of Forces for Democracy and Development (UFDD) which is a coalition of small armed groups and army deserters who have been launching cross border attacks on Chad from Darfur since 2005. Such attacks have been said to be responsible for the violence which has forced 180,000 Chadians to flee their homes. Similarly, the Central African Republic (CAR) has accused Sudan of backing the Union of Democratic Forces for Unity (UFDR) rebels who seized some towns in north-eastern Central African Republic. The government alleged that the UFDR were operating from Darfur with the support of the Sudanese authorities. In fact, there were plans by the government of Chad to send troops to Central African Republic to help the government fight these rebels attacking its northern part. Chad also accused Sudan of attempting to destabilize both Chad and Central African Republic and suggested an anti- Sudan alliance (BBC News, 6th December, 2006).

It is also obvious that the conflict seriously affected the overall social and economic development of the country. This is because the resources that should have been used in providing good drinking 
water to the people, electricity supply, education, accessible roads and others have been diverted to fighting the war. General Martin L. Agwai (2007), the new chairman of the Joint African Union/ UN Hybrid operation in Darfur, recently mentioned these issues as some of the major obstacles to the combined UN/AU forces assignment in Darfur. He noted that lack of roads and communication generally and some basic amenities like portable drinking water are already impediments toward restoring peace.

\section{Towards finding a lasting Peace in Darfur}

The conventional approach to solving conflicts and crisis situations in war- torn areas has always been by drafting a peace keeping force into an area and providing aid to victims and sometimes imposing sanctions. As a short term measure this approach works but in the long run it does not. This can be seen in the case of other places like Somalia and other strife- torn countries such as Iraq, Afghanistan etc. This measure has also not worked in the case of Darfur. The deployment of some 7000 peacekeepers in 2004 by the African Union with the mandate to observe the 'Darfur Peace Agreement of 2006' and the more than 9000 uniformed personnel on the ground now including 7000 troops and 1200 police serving with the AMIS as well as the UNAMID hybrid force, have not been able to bring the fighting to an end. The murder, rape and pillage have continued unabated and the AU officials are not spared either. Since the deployment of AU troops in 2004 about 15 of them have been killed, supposedly, by the rebel gangs (The Guardian Newspapers, 2nd April, 2007). This failure on the part of AU has rightly been attributed to lack of enough troops and equipment. The plans to boost the security situation in Darfur by drafting a hybrid UN/AU force of 19,555 troops under the first plan and another 17,605 with a police component of 3,772 officers, 18 utility helicopters and about 12-18 combat helicopters; under the assumption that these forces can bring to an end the crisis in the region, is a delusion. The editorial of the Gambian Newspapers, (The Daily Observer, 9th July, 2007) was optimistic that peace would come to Sudan as soon as a larger and better- equipped force 
operating under the UN and AU was deployed to Darfur, but this is far from the truth. The best any peacekeeping force can do is to restore the security conditions for the safe provision of humanitarian assistance and protect civilian populations that are under imminent threat of attacks but it cannot provide a lasting peace. Paul Moorcraft (2007) correctly pointed out that peacekeepers cannot keep a peace that does not exist and even if all US troops in Iraq were suddenly transplanted to Darfur, they would not be able to police a region or keep the peace. He has also faulted the timing of the sanctions imposed on a region that is trying to rebuild itself and develop its economy after 50 years of war.

Hence what is required in the case of the Darfur crisis was a political solution to a political problem. As the governor of north Darfur pointed out, "there could be no winning in this war", so there is the need to engage in a very genuine and more sincere dialogue between all the factions fighting in the area. The previous attempts at reconciling the different fighting factions were not successful, largely because some of the groups are still aggrieved. It is to be noted that not all the rebel groups signed on to the pact in Abuja, Nigeria in 2006. In fact only one of the three rebel groups signed the agreement leaving the conflict unresolved. Similarly, the meeting in Libya of 15th -16th July, 2007, to discuss the road map for peace in Sudan ran into problem before it even started with the SLM headed by the Parisbased Abdulwahid Mohammed (2007) declaring that they won't recognize the outcome of the Tripoli meeting. It is significant to note that, Omar al-Bashir has for long resisted UN peacekeepers to enter Darfur because of his fear that Sudan would be turned into another Iraq and on one occasion said that the key to ending the conflict rested with the Sudanese. He told the parliament that the solution to the crisis must be a national responsibility with the sons and daughters of Sudan. This is quite true. The crisis in Darfur is an internal problem and needs an internal solution. There should be internal machinery that could trigger dialogue with all the nine rebel movements which have grown and splintered into factions since 2003. 
The peace talks at the Libyan town of Sirte of 29th October, 2007 under the auspices of the UN and the AU was a good starting point but more should be done to bringing the key rebel groups of JEM and SLA/M to the negotiating table. It is to be noted that only 7 armed groups turned up at Sirte out of 16 (Guest Column 5th December, 2007). It is also important to include the representatives of civil society groups, the grassroots level in the form of leaders from different ethnic groups, the women, the displaced persons and the refugees. Neighbouring countries that receive thousands of these refugees and have influence over various rebel movements and the National Congress Party could also be included in such mediation attempts so that peace could return to the whole region. It was equally suggested that full participation at this mediation could be achieved by either convening a Darfur- wide forum with representatives of all constituencies or by expanding the consultations conducted earlier in 2007 through the existing moribund Darfur Dialogue and Consultation Process.

\section{Conclusion:}

The conflict in Darfur is certainly the shame of Africa. Contrary to the views expressed, however, of reducing the conflict to being caused by tribalism or ethnic sentiments, marginalization or genocide, we have shown that the crisis was rooted within the internal political dynamics of the Sudanese society. This paper has been able to establish the impact of the crisis on Sudan, the entire region and the continent as a whole. It is another example of the kind of senselessness, greed and avarice that is typical of the African ruling elite; the extent to which they can go to perpetuate and sustain themselves in power no matter the cost in human life and suffering. The combatants in Darfur have clearly demonstrated their insensitivity to the summary executions, sexual violence, and acts of torture, pillaging and displacements of unimaginable magnitude that have taken place over the last five years. The crisis can only be resolved through sincere and honest discussion among all the factions and other interest groups and not by the presence of some peacekeeping forces. Peace can only come from 


\section{within and can be obtained through dialogue. It is time to end this human calamity.}

\section{References}

Abdulwahid Mohammed (2007) "Sudan: Darfur Actors to discuss Road Map for Peace" Integrated Regional Information Networks, 11th July, http://www.allafrica.com).

Africa Focus (2006) "Sudan: Why Doesn't Bush Act on Darfur?" (Washington DC) 29th December.

Africa On line (2004) "Sudan Rebels Form Alliance against Government", 28th January.

Agence France Presse (2004) "Nigeria's Obasanjo Unconvinced on US Call of Genocide in Darfur", News Article, 3rd December.

Alex de-Waal (2006). "Tragedy in Darfur: On Understanding and Ending the Horror", Boston Review, Vol. 29, No.5, October-November http:www.darfurinperspective.com

Al- Hayat( English edition) (2007). Dynasty <http://en.wikipedia.org/wiki/keira > 13th April.

Aljazeera (2004) "EU Mission Finds no Evidence of Darfur Genocide", News Article, 10th August.

Ateem Selsi (2004). "Confronting the Crisis in Darfur", A Transatlantic Assessment, Brussels: Trans. Institute, 12th May

BBC News (2006a). "Peacekeeping in Darfur" http://www.bbcnews.com 1st December.

BBC News (2006b). "Darfur Conflict Zones Map" http://www.bbcnews.com, 6th December

BBC News (2007a) "World/Africa Analysis: Defining Genocide." http://www.bbcnews.com February, 27.

BBC News (2007b) "Hopes Fade for Solution to Darfur", http://www.bbcnews.com, 3rd April.

Brado (2004) "From one Genocide to Another." http://www.msfuea.ae 28th September.

Deibert, Micheal (2007). "Sudan: Do Something Now Because People Are Dying Everyday", Interpress Service (Johannesburgh), 30th April.

Deutche Press Agentur (2004a) "Sudan Calls on UN to Take Action Against Eritrea", 5th January.

Deutche Press Agentur (2004b). "No Genocide in Sudan, Annan says", News Article, 17th June.

Eric Reeves (2004a) "Stoping Genocide in Darfur: What Must Be Done", 17th May. http: sudanrevees.org.

Eric Reeves (2004b). "The Data of Destruction: Accelerating Genocide in Darfur" 27th May. http:sudanreeves.org.

Eric Reeves (2004c). "Quantifiying Genocide in Sudan: A Summary and Update” 28th May.

Flint and de wall, (2006) Darfur: A Short History of a Long War. London: Zed books.

Ghazi S. (2004). "Editorial Comment." Knight Ridder Newspapers, 20th August.

Guest Column (2007) "Sudan: Darfur Peace Efforts Must Embrace New Reality", www.allafrica.com, 5th December.

Hoile, D. (2005), "Darfur in Perspective", Published by the European- Sudanese Public Affairs,

Human Rights Watch (2007a) "Sudan: Sudan- US Sanctions Welcome but Overdue", (Washington DC), 29th May.

Human Rights Watch (2007b) "China's Involvement in Sudan: Arms and Oil”, 23rd December.

Integrated Regional Information Networks (2003) "Escalating Crisis in Darfur" News Article, 31 st December.

Interpress Service (2007) "Sudan: Do Something Now Because People Are Dying Every Day", (Johannesburg) 30th April 
Jean- Herve Bradol (2004). "From one Genocide to Another", 28th May. http://www.msfuae.ae Jihad al- Khazen (2007). "Since the Victims are Arabs and Muslims", In Al- Hayat (English Edition) 13th April. Cited in http://en.wikipedia.org/wiki/keiradynasty

Martin L. Agwai (2007) Chairman of the Joint African Union/ UN Hybrid operation in Darfur http://www.allafrica.com 6th November.

Middle East International (2005). "Peace Still Some Way off in Sudan.” London, 8th January.

Morgalis E. S. (2004). "No time for a Crusade in Sudan", 12th August. http://www.darfurinperspective.com

News From Africa (2004) "What Kind of Intervention Will Work in Darfur", Nairobi, August.

News Report (2007) "The Increasing Importance of African Oil”, Power and interest, 20th March.

Nicholas Kristof (2004), "Cruel Choices, Sudan: Hundreds of Children Missing after Darfur Attack" UN Integrated Regional Information Networks, The New York Times 14th February.

PANA (2004) "Bashir sets up panel to probe Human Rights Abuses in Darfur", News Article, 9th May.

Paul Moorcraft (2007), "Sudan: Strange Bedfellows in Khartoum", Business Day (Johannesburg), 22nd June.

Peter Quayle (2005). "Grave Crimes." London: The Royal Institute of International Affairs, The World Today, Vol. 61, No. 1, January.

Report of the International Commission of Inquiry on Darfur to the UN Secretary General (PDF) UN, 25th January 2006.

Reuters (2004a) "EU Mission Sees Abuses but not Genocide in Darfur", News Article 9th August.

Reuters (2004b) "Sudan: Islamists Used Darfur as Battleground", 22nd September

Reuters (2004c). "Darfur Governor Links Khartoum Plot with Rebels", 26th September.

Sudan Tribune (2007). "On Darfur, China and 2008 Games." 11 th February.

Sudan Vision (2004). "Darfur: Rebel Attacks Stops Water Supply Project", (Khartoum) 7th June.

Surdarsan Raghavan (2004). "Sudan Violence is Part of Power War", Knight Ridder Newspapers, 20th August.

Tajudeen Abdul- Raheem (2004) In News from Africa, Nairobi, August. http://www.allafrica.com).

The Daily Observer (2007) "Gambia: Ending Darfur Crisis”, (Banjul), 9th July.

The Elders (London) Press Release (2007) "Sudan: "The Elders Urge Immediate Action on Darfur", 4th December. www.theElders.org

The Financial Times (2004) “The Black Book History or Darfur's Darkest Chapter", (London) 21st August.

The Guardian Newspapers (2007) "Gunmen Killed Five AU Peacekeepers.” 2nd April. http://www.atimes.com/atimes/Globaleconomy

The New York Times (2004) "In Sudan No Clear Difference Between Arab and African" 3rd October.

The Observer (2004). "Empty Villages Mark Trail of Sudan's Hidden War.” London, 30th May, 2004.

The Wall Street Journal (2007) “The Genocide Olympics”, 28th March.

The White House (2007) "Sudan: President Bush Discusses Darfur, Implements Sanctions", Washington DC, 29th May.

UN Integrated Information Networks (2008) “Chad: Darfur Refugees Denounce Rebellion”, 4th February, 2008. 
UN Integrated Regional Information Networks (2007a) "Sudan: Darfur Actors to Discuss Road Map for Peace", 11 th July.

UN Integrated Regional Information Networks (2007b) "Sudan: Unarmed Darfur Groups Demand Role at Peace Talks", 29th October.

UN Integrated Regional Information Networks (2007c) "Sudan: Waiting for Peacekeeping Muscle in Darfur", 31st December.

UN News Service (2006) "Sudan: Secretary General Transmits Report on Darfur Hybrid Force", (New York), 6th June.

UN News Service (2007) "Sudan: Darfur-UN Mission Reports New Round of Clashes", (New York) 21th May.

UN News Service (2008a) "Sudan: Displaced Darfurians Moving to New Camp, Others Flee to Chad, UN Says", (New York) 26th February.

UN News Service (2008b). "Sudan: Attacks on Aid Workers in Darfur Threatening Relief Efforts", (New York) 31st December.

UN News Service (op cit) "Sudan: Banki-Moon Voices Concern Over Violence in West Darfur between Rebel Group/ Government", (New York) 31st December.

Wikipedia, the Free Encyclopedia. "Conflict", http://en.wikipedia.org/wiki/keiradynasty

http://www.reliefweb.org http://www.sudan.gov.sd (2004). "Understanding the Darfur Conflict", Khartoum, December.

www.allafrica.com (2007) "Sudan: Darfur Peacekeepers Warns of High Expectations", 6th November.

http://www.reliefweb.org, http://www.sudan.gov.sd (2007) "Understanding the Darfur Conflict", Khartoum, December. 